\title{
THE COMPOSITION OF GOVERNMENT EXPENDITURES AND ECONOMIC GROWTH IN BOLIVIA*
}

\section{Antonio N. Bojanic ${ }^{* *}$}

This paper analyzes the relationship between economic growth and productivity to budget share ratios of government expenditures in Bolivia since 1940. Government expenditures are classified according to their functional and economic characteristics and place of origin. The results indicate that defense expenditures, decentralized expenditures (local or regional), and expenditures in Santa Cruz Department represent the best ways for government to boost the country's growth. Expenditures on additional areas, such as education, and in other promising departments, such as Beni and Oruro, have the potential for generating significant growth and should be considered areas for possible government intervention.

JEL classification: E62; H50; O40; O54

Keywords: Bolivia, productivity of government expenditures, economic growth, generalized method of moments

\section{INTRODUCTION}

Governments in developing countries spend upwards of 40 percent of GDP on goods and services. ${ }^{1}$ In Bolivia, the figure has revolved around 35 percent between 2006 and 2010, but an ascending trend is inevitable as the current government has explicitly stated that it aims to control a far larger share of the economy. ${ }^{2}$

The growing importance of government expenditures in most countries has prompted a significant amount of research on the relationship between the size of government and economic growth. The results of these empirical studies are not generally supportive of the notion that bigger government produces economic growth (see, for instance, Lindauer, et al., 1992 and Fölster, et al., 2001), yet when government

\footnotetext{
* The author wishes to thank Leland Yeager and anonymous referees for detailed criticisms and suggestions. The author alone is responsible for any errors that remain.

** Professor of Economics, Universidad Nuestra Señora de La Paz, Calle Presbítero Medina 2412, La Paz, Bolivia. Telephone: 1 (703) 475-7739. Email: antonio.bojanic@unslp.edu.bo.

1. Retrieved from http://data.worldbank.org/indicator/GC.XPN.TOTL.GD.ZS.

2. For a typical reference to this explicit government aim, as reflected in the views of the vice president of Bolivia, see http://www.desdeabajo.info/index.php/actualidad/internacional/6178-alvaro-garcia-lineravicepresidente-bolivia-es-un-estado-integral-que-transita-al-socialismo-y-que-inicia-una-decada-de-oro.htm.
} 
expenditures are disaggregated into their different components, the results are not as clear-cut. For instance, Hakro (2009) found that for a set of 21 Asian countries, investment in physical capital is positively correlated with growth in GDP per capita. Romero-Avila, et al. (2008), however, found that government size, measured in terms of total expenditures or government consumption, has a negative effect on the growth rates of income per capita in a set of 15 European countries. More recently Bayraktar, et al. (2010) studied the effect on growth of different components of public spending for sets of rapidly growing and more stagnant developing countries and found that public spending can be a significant determinant of growth for countries that are capable of using funds for productive purposes.

Current research on this subject is focused on how the composition of public expenditure affects a country's growth rate (representative works in this line are Devarajan et al., 1996 and Sugata et al., 2008) and the distinction between productive and unproductive expenditures (for instance, Aschauer, 1998, and Nurudeen et al., 2010). The latter area of research is particularly important today as governments around the world scramble to put their fiscal houses in order by cutting components of public expenditures that are deemed less efficient, unsustainable, or simply less likely to help in achieving their goals. Vera and Fiestas (2005) provided one of the few studies that analyzes the link between public spending, poverty reduction and growth in Bolivia and in eight other developing nations. Their findings suggest that education as a share of GDP has a strong, positive influence on both poverty reduction and income, but the impact of health expenditures on growth is either weak or insignificant for the sample of countries studied.

The purpose of this paper is to shed light on the relationship between productivity to budget share ratios of different types of government expenditures and economic growth in Bolivia. It contributes to the current literature in several ways: (i) it builds on the work of Devarajan et al. (1996) by actually estimating productivity to budget share ratios for different types of government expenditures and analyzing their impact on Bolivia's economic growth. While the theoretical section of Devarajan et al. develops the analysis presented here, the empirical section of that paper only considers the effect on economic growth of budget-share ratios. Here, I actually estimate the productivity to budget share ratios conceived by Devarajan et al. and study their impact on real GDP per capita; (ii) additionally, whereas Devarajan et al. 
concentrated only on the effect of so-called functional and economic public expenditures on economic growth, here I add a third dimension, namely public investment decentralized at the department ${ }^{3}$ level, to determine its impact on the country's per-capita GDP growth. This paper is the first attempt to measure the significance of public investment by the departments to explain the country's economic growth; and (iii) this paper is one of a handful ${ }^{4}$ of papers that concentrates solely on Bolivia, utilizing the largest dataset available for the country.

In addition to the aforementioned contributions, the value added of studying the relationship between productivity to budget share ratios of different types of government expenditures and economic growth lies in determining what types of government expenditures have worked and what other types have not worked since 1940. In a nation with a complex history of public intervention and dramatic needs that must be addressed to reduce the extreme poverty observed in certain regions of the country, identification of those types of public expenditures that have the potential to generate a positive impact on economic growth is certainly a welcome contribution.

At the start, it is important to note that government expenditures do not have the sole objective of increasing per-capita income, and may indeed have alternative goals. In today's Bolivia, alternative objectives of public investment may play a far more significant role than would be expected in most other nations. However, increasing income per capita is certainly an objective of most governments, hence measuring the contribution of different components of expenditure to achieve this objective seems natural. Additionally, per-capita income is easier to measure than other objectives of government policy.

This paper is organized as follows: Section 2 develops an analytical framework that links productivity to budget share ratios of different types of public expenditures to economic growth. Section 3 presents the empirical model, including a brief description of the functional, economic and department classifications that are made to distinguish between different types of government expenditures. Section 4 introduces the data and its sources. The results are presented in Section 5. Section 6 concludes.

3. Bolivia is divided into nine departments.

4. The other paper I am aware of is Machicado et al. (2010), but the emphasis of their work was the links between fiscal policy, economic growth and the sustainability of social transfers. 


\section{A MODEL LINKING PRODUCTIVITY-BUdGET SHARE RATIOS WITH ECONOMIC GROWTH}

For several decades researchers have been looking at the relationship between fiscal policy and the economy's growth rate. The seminal contribution to this literature was that of Arrow and Kurz (1970), who developed a model in which consumers derive utility from private consumption as well as public capital stock. They argued that public capital plays a pivotal role in inducing growth, giving credence to the belief that governments can affect a country's economic wellbeing. Later contributions by others, notably Barro (1990, 1991), also produced alternative models linking government expenditures with a country's economic growth.

Here, and drawing on an earlier theoretical framework that evidenced the efficiency of different types of public spending, a model is postulated in which there are two types of government expenditures: productive and unproductive. ${ }^{5}$ Assuming a constant elasticity of substitution (CES) technology with three arguments - private capital, $k$, and two types of government spending, $g_{1}$ and $g_{2} \mathrm{~s}$ - the aggregate production function is given by

$$
y=f\left(k, g_{1}, g_{2}\right)=\left[\alpha k^{-\zeta}+\beta_{i} g_{1}^{-\zeta}+\beta_{j} g_{2}^{-\zeta}\right]^{-1 / \zeta}
$$

where

$$
\alpha>0, \beta_{i} \geq 0, \beta_{j} \geq 0, \alpha+\beta_{i}+\beta_{j}=1, \zeta \geq-1
$$

The government's budget constraint is

$$
\tau y=g_{1}+g_{2}
$$

and $\tau$ is the (constant over time) income tax rate.

The shares of government expenditure that go toward $g_{1}(\phi)$ and $g_{2}(1-\phi)$ are given by

$$
g_{1}=\phi \tau y \text { and } g_{2}=(1-\phi) \tau y
$$

where $0 \leq \phi \leq 1$. 
Assuming the representative agent's utility function is isoelastic, utility is derived from private consumption, $c$, and is given by

$$
U=\int_{0}^{\infty} \frac{c^{1-\sigma}-1}{1-\sigma} e^{-\rho t} d t
$$

with $\rho(>0)$ representing the rate of time preference.

The agent's budget constraint is

$$
\dot{k}=(1-\tau) y-c
$$

Devarajan et al. (1996) derived the following expressions for the ratio between total government spending $\left(g=g_{1}+g_{2}\right)$ and private capital, $g / k$,

$$
\frac{g}{k}=\left[\frac{\tau^{\zeta}-\beta_{i} \phi^{-\zeta}-\beta_{j}(1-\phi)^{-\zeta}}{\alpha}\right] 1 / \zeta
$$

and for the economy's endogenous growth rate, $\lambda$,

$$
\lambda=\frac{\alpha(1-\tau)\left\{\alpha \tau^{\zeta} /\left[\tau^{\zeta}-\beta_{i} \phi^{-\zeta}-\beta_{j}(1-\phi)^{-\zeta}\right]\right\} \frac{1+\zeta}{\zeta}-\rho}{\sigma}
$$

The relationship between the country's endogenous growth rate, $\lambda$, and the share of expenditure devoted to $g_{1}$ is given by

$$
\frac{d \lambda}{d \phi}=\frac{\alpha(1-\tau)(1+\zeta)\left[\alpha \tau^{\zeta}\right]^{-\frac{1+\zeta}{\zeta}}\left[\beta_{i} \phi^{-(1+\zeta)}-\beta_{j}(1-\phi)^{-(1+\zeta)}\right]}{\sigma\left[\tau^{\zeta}-\beta_{i} \phi^{-\zeta}-\beta_{j}(1-\phi)^{-\zeta}\right]^{-1 / \zeta}}
$$

Thus, a productive expenditure ${ }^{6}$ is defined as one whose increase in its share raises $\lambda$. From Equation (8), $g_{1}$ is considered productive if $d \lambda / d \phi>0$.

Having defined a productive expenditure, the model proposed by Devarajan, et al., (1996) collapses to a situation where the growth rate of an economy depends not just on the absolute productivity of different types of expenditures but also on the initial shares of these expenditures in the government's budget. Formally, when there are $N$ types of government expenditures, each with its own productivity, $\beta_{i}$, in

6. "Productive government expenditure" refers to productivity in relative terms: the extent by which an increase in the budget share of a particular type of expenditure increases the country's endogenous growth rate. On the other hand, "government expenditure productivity" refers to productivity in absolute terms: the coefficient of each type of government expenditure in the production function. 
the production function, and share $\phi_{i}$ in the budget, then the effect on growth of increasing the share of government expenditure going to the $i$ th component depends on which component's share is being reduced. If the increase in $i$ 's share comes from a component $j$ such that

$$
\frac{\beta_{i}}{\phi_{i}}>\frac{\beta_{j}}{\phi_{j}}
$$

then the shift in expenditure composition will increase the growth rate of the economy. Alternatively, if the inequality above were reversed, then a shift from $j$ to $i$ would lower the country's long-run growth rate.

Despite some obvious limitations-i.e., it takes the government's decisions as given and all government expenditures are assumed to affect the production function - the model that has just been described yields important insights into what makes particular components of government expenditure productive. It shows that in addition to each component's productivity, its actual share in the budget determines whether it is considered a productive component or not.

In the following sections I examine Bolivia's growth performance since 1940 and how it has been affected by different types of government expenditures. Specifically, I estimate the productivity and the budgetshare ratios of different types of government expenditures, and based on these results, I estimate productivity to budget share ratios to determine their impact on per-capita income growth in the country during the last several decades.

\section{The Empirical Model}

The generalized method of moments (GMM) is used to estimate the following equation:

$$
\text { Ycapita }_{t}^{i}=a_{i}+\alpha_{1}\left(\frac{\text { trade }_{\text {gdp }}}{{ }_{t}}+\alpha_{2}\left(\frac{\beta_{g e}}{\phi_{g d p}}\right)_{t}^{i}+\alpha_{3}\left(\beta / \phi_{g e}\right)_{t}^{i}+\mu_{i}\right.
$$

Where Ycapita $_{t}^{i}$ is the four-year forward moving average of real GDP per capita at time $t ;(\operatorname{trade} / g d p)_{t}^{i}=$ is a trade openness indicator estimated by adding total exports and imports (trade) and dividing the result by GDP; $\left(\beta_{g e} / \phi_{g d p}\right)_{t}^{i}$ is the ratio of the productivity of total government expenditures to share of total government expenditures in GDP at time $t$; and $\left(\beta / \phi_{g e}\right)_{t}{ }_{t}^{i}$ is the ratio of productivity of functional, economic, and department public expenditures on shares of functional, economic, and 
department public expenditures in total government expenditures at time $t .{ }^{7}$ The trade openness indicator, $($ trade $/ g d p){ }_{t}^{i}$, is included in all specifications as a control variable, ${ }^{8}$ while the variable $\left(\beta_{g e} / \phi_{g d p}\right)_{t}{ }^{i}$ is also included in all specifications to control for level effects.

In functional productivity to budget share ratios, $\beta_{e d u} / \phi_{g e}$ is the ratio of productivity of education expenditures to share of education expenditures in total government expenditures; $\beta_{d e f} / \phi_{g e}$ is the ratio of productivity of defense expenditures to share of defense expenditures in total government expenditures; $\beta_{\text {health }} / \phi_{g e}$ is the ratio of productivity of health expenditures to share of health expenditures in total government expenditures; and $\beta_{\text {infra }} / \phi_{g e}$ is the ratio of productivity of infrastructure expenditures to share of infrastructure expenditures in total government expenditures.

Economic productivity to budget share ratios comprise the following variables: $\beta_{\text {curr Central }} / \phi_{g e}$ is the ratio of productivity of current expenditures by the central government to share of current expenditures by the central government in total government expenditures; $\beta_{\text {capCentral }} / \phi_{g e}$ is the ratio of productivity of capital expenditures by the central government to share of capital expenditures by the central government in total government expenditures; $\beta_{\text {currLocal }} / \phi_{\text {ge }}$ is the ratio of productivity of current expenditures by local governments to share of current expenditures by local governments in total government expenditures; $\beta_{\text {capLocal }} / \phi_{g e}$ is the ratio of productivity of capital expenditures by local governments to share of capital expenditures by local governments in total government expenditures; $\beta_{\text {curr Comp }} / \phi_{\text {ge }}$ is the ratio of productivity of current expenditures by government companies to share of current expenditures by government companies in total government expenditures; and $\beta_{\text {capComp }} / \phi_{g e}$ is the ratio of productivity of capital expenditures by government companies to share of capital expenditures by government companies in total government expenditures.

7. The classification of government expenditures used by the International Monetary Fund is utilized in this work. The IMF classification follows two main lines: (i) the economic classification of expenditure, which is based on the type or economic characteristics of expenditure, such as current and capital expenditures; and (ii) the functional classification, which is based on the purpose or function toward which the expenditure is directed (examples include expenditures on education, health, defense and infrastructure). Here, I add a third dimension of expenditures, namely, department classification to highlight investment expenditures of Bolivia's nine departments.

8. The trade openness indicator was chosen as a control variable in all regressions because of the ready availability of data since 1940. For the department classification results, an economic risk indicator (available at http://prsgroup.com/ICRG_indicators and published by Political Risk Services Group) was also utilized, but it did not significantly modify the results. Hence, results of all regressions are only reported with the trade openness indicator. 
Department productivity-budget share ratios are estimated for the nine departments that constitute Bolivia, namely: Beni $\left(\beta_{\text {beni }} / \phi_{g e}\right)$, Cochabamba $\left(\beta_{c b b a} / \phi_{g e}\right)$, Chuquisaca $\left(\beta_{\text {chuq }} / \phi_{g e}\right)$, Oruro $\left(\beta_{\text {oruro }} / \phi_{g e}\right)$, Pando $\left(\beta_{\text {pando }} / \phi_{g e}\right)$, La Paz $\left(\beta_{l p z} / \phi_{g e}\right)$, Potosí $\left(\beta_{\text {potosi }} / \phi_{g e}\right)$, Santa Cruz $\left(\beta_{s c z} / \phi_{g e}\right)$, and Tarija $\left(\beta_{\text {tarija }} / \phi_{g e}\right)$. Additionally, the productivity to budget share ratio of aggregate national investment to total government expenditures $\left(\beta_{\text {national }} / \phi_{g e}\right)$ is included to account for the effect of total national investment on growth.

The parameters of the equation are $a_{i}, \alpha_{1}, \alpha_{2}$ and $\alpha_{3}$. The error term is $\mu_{i}$.

\section{DATA}

The empirical analysis uses annual data on real GDP per capita, the ratio of total trade (exports + imports) on GDP, the productivity to budget share ratio of total government expenditures to share of total government expenditures in GDP, and productivity to budget share ratios of functional, economic, and department expenditures to shares of functional, economic, and department expenditures in total government expenditures. All variables, in levels, are expressed in U.S. dollars. The base year for all variables is 2000. All data have been obtained from the Statistical Bulletins and the Annual Reports of the Central Bank of Bolivia, ${ }^{9}$ the Bolivian National Institute of Statistics, ${ }^{10}$ and the World Bank. ${ }^{11}$ The relationship between economic growth and productivity to budget share ratios by functional classification covers the period 1940-2010. The same relationship in terms of the economic classification of expenditures runs from 1965 to 2010. The analysis by department classification covers the 1988-2010 period. ${ }^{12}$ All the data series have been transformed to the logarithmic form to achieve stationarity in variance. ${ }^{13}$

9. Data from approximately 1970 and onwards can be obtained at the following link: www.bcb.gob. bo $/ ? \mathrm{q}=$ publicaciones/boletin_estadistico\&cbo $2=-1 \&$ cbo3 $=0$. Older data must be accessed manually at the historical archives of the Central Bank of Bolivia.

10. As was the case with the Central Bank, data from approximately 1970 and onwards can be obtained at www.ine.gob.bo/indice/indice.aspx. Older data must be accessed manually at the historical archives of the National Institute of Statistics.

11. Retrieved from http://data.worldbank.org

12. Values for 2010 are preliminary.

13. When the productivity of certain types of government expenditures are found to be negative, the productivity to budget share ratios of these government expenditures are not transformed to the logarithmic form. This situation occurs for total government expenditures during the 1940-2010 period; expenditures on health, capital expenditures by the central government, current and capital expenditures by local governments, and expenditures in the departments of Beni, Chuquisaca, Pando, La Paz, Potosí, and Santa Cruz. 
The four functional government expenditures that have been targeted are health, defense, education, and infrastructure. ${ }^{14}$ Values apportioned to each of these sectors represent monetary expenditures, in current U.S. dollars, as reflected in end-of-year government budgets. Government statistics distinguish among these four types of functional expenditures since 1940, hence the period analyzed runs from 1940 through 2010.

Economic expenditures, also in current U.S. dollars, include current and capital expenditures by three different levels of government: central government, local or regional governments and government-run companies. Disaggregated official statistics that differentiate among these different types of expenditures ${ }^{15}$ begin in 1965 , hence the period analyzed covers 1965-2010.

Finally, department expenditures in current U.S. dollars represent capital expenditures in each of the nine departments of the nation. Official statistics on capital investments in each department are only available from 1988 onwards, therefore the period of analysis is 1988-2010.

An introduction to all variables utilized in this work appears in Appendix A, where unit root tests using the augmented Dickey-Fuller test (ADF test) ${ }^{16}$ and the Phillips and Perron test (PP test) ${ }^{17}$ are presented. According to the applicable test statistics reported by MacKinnon (1991), most variables are integrated of order one, or $I(1)$.

\section{Results}

Before analyzing the relationship between economic growth and productivity to budget share ratios for different types of government expenditures, government expenditure productivities by functional, economic, and department classifications must be estimated. Table 1 below provides GMM estimates of these productivities. ${ }^{18}$

14. The infrastructure category includes expenditures in transportation, communications, housing, and other economic services such as electricity and sewer infrastructure.

15. Current expenditures include operation costs, salaries, purchase of goods and services, leasing contracts, interest payments on public debt, and certain transfers to local governments, state-run companies, and to the private sector. Capital expenditures include investment in infrastructure, capital amortization on public debt, and capital transfers to local governments, state-run enterprises, and some decentralized government institutions.

16. For a detailed analysis of the implications of this test see Dickey, et al. $(1979,1981)$.

17. The Phillips-Perron test is developed in Phillips, et al. (1988).

18. Table 1 presents a summary of the key findings in each of the regressions that were run to obtain estimates of public expenditure productivities. Since the dependent variable in all cases was the fouryear moving average of real GDP per capita, serial correlation in the error term was expected. Hence, productivities were obtained using the generalized method of moments (GMM). All specifications include a trade openness indicator (trade/gdp) as a control variable. Functional productivities are obtained for the period 1940-2010; economic productivities are estimated for the period comprised between 1965 and 2010 and department productivities are estimated for the 1988-2010 period. 
Table 1. GMM estimates of public expenditure productivities by functional, economic, and department classifications

\begin{tabular}{|c|c|c|c|}
\hline & $\begin{array}{l}\text { Functional } \\
\text { productivities }\end{array}$ & $\begin{array}{c}\text { Economic } \\
\text { productivities }\end{array}$ & $\begin{array}{c}\text { Department } \\
\text { investment } \\
\text { productivities }\end{array}$ \\
\hline $\begin{array}{l}\text { Productivity of total government } \\
\text { expenditures, } 1940-2010\left(\beta_{g e 1}\right)\end{array}$ & $\begin{array}{c}-0.4335 \\
(-1.02)\end{array}$ & & \\
\hline $\begin{array}{l}\text { Productivity of public expenditure } \\
\text { on education }\left(\beta_{e d u}\right)\end{array}$ & $\begin{array}{l}1.2136 \\
(1.24)\end{array}$ & & \\
\hline $\begin{array}{l}\text { Productivity of public expenditure } \\
\text { on defense }\left(\beta_{d e f}\right)\end{array}$ & $\begin{array}{l}0.1248 \\
(1.12)\end{array}$ & & \\
\hline $\begin{array}{l}\text { Productivity of public expenditure } \\
\text { on health }\left(\beta_{\text {health }}\right)\end{array}$ & $\begin{array}{r}-1.6790 \\
(-0.90)\end{array}$ & & \\
\hline $\begin{array}{l}\text { Productivity of public expenditure } \\
\text { on infrastructure }\left(\beta_{\text {infra }}\right)\end{array}$ & $\begin{array}{c}1.0645^{* *} \\
(2.34)\end{array}$ & & \\
\hline $\begin{array}{l}\text { Productivity of total government } \\
\text { expenditures, 1965-2010 }\left(\beta_{g e 2}\right)\end{array}$ & & $\begin{array}{l}1.6771 \\
(1.98)\end{array}$ & \\
\hline $\begin{array}{l}\text { Productivity of current expenditures } \\
\left.\text { of central government ( } \beta_{\text {currCentral }}\right)\end{array}$ & & $\begin{array}{l}2.5993^{* *} \\
(2.19)\end{array}$ & \\
\hline $\begin{array}{l}\text { Productivity of Capital expenditures } \\
\text { of central government }\left(\beta_{\text {capCentral }}\right)\end{array}$ & & $\begin{array}{c}-1.3175^{* *} \\
(-2.31)\end{array}$ & \\
\hline $\begin{array}{l}\text { Productivity of current expenditures } \\
\text { of local governments }\left(\beta_{\text {currLocal }}\right)\end{array}$ & & $\begin{array}{c}-1.5488^{* *} \\
(-2.38)\end{array}$ & \\
\hline $\begin{array}{l}\text { Productivity of capital expenditures } \\
\text { of local governments }\left(\beta_{\text {capLocal }}\right)\end{array}$ & & $\begin{array}{r}-1.2950 \\
(-1.37)\end{array}$ & \\
\hline $\begin{array}{l}\text { Productivity of current expenditures } \\
\text { of state companies }\left(\beta_{\text {curr Comp }}\right)\end{array}$ & & $\begin{array}{l}0.5045 \\
(0.71)\end{array}$ & \\
\hline $\begin{array}{l}\text { Productivity of capital expenditures } \\
\text { of state companies }\left(\beta_{\text {cap Comp }}\right)\end{array}$ & & $\begin{array}{c}0.0013 \\
(0.04)\end{array}$ & \\
\hline $\begin{array}{l}\text { Productivity of total government } \\
\text { expenditures, 1988-2010 }\left(\beta_{g e 3}\right)\end{array}$ & & & $\begin{array}{l}0.6846 \\
(0.57)\end{array}$ \\
\hline $\begin{array}{l}\text { Productivity public investment } \\
\text { in Beni }\left(\beta_{\text {beni }}\right)\end{array}$ & & & $\begin{array}{r}-1.1761 \\
(-1.87)\end{array}$ \\
\hline $\begin{array}{l}\text { Productivity public investment } \\
\text { in Cochabamba }\left(\beta_{c b b a}\right)\end{array}$ & & & $\begin{array}{c}0.4162 \\
(0.22)\end{array}$ \\
\hline $\begin{array}{l}\text { Productivity public investment } \\
\text { in Chuquisaca }\left(\beta_{\text {chuq }}\right)\end{array}$ & & & $\begin{array}{c}-0.0064 \\
(0.01)\end{array}$ \\
\hline $\begin{array}{l}\text { Productivity public investment } \\
\text { in Oruro }\left(\beta_{\text {oruro }}\right)\end{array}$ & & & $\begin{array}{l}1.1663 \\
(0.71)\end{array}$ \\
\hline $\begin{array}{l}\text { Productivity public investment } \\
\text { in Pando }\left(\beta_{\text {pando }}\right)\end{array}$ & & & $\begin{array}{c}-0.4813 \\
(-1.41)\end{array}$ \\
\hline $\begin{array}{l}\text { Productivity public investment } \\
\text { in La Paz }\left(\beta_{l p z}\right)\end{array}$ & & & $\begin{array}{l}-1.7013 \\
(-1.45)\end{array}$ \\
\hline
\end{tabular}


Table 1. (continued)

\begin{tabular}{|c|c|c|}
\hline $\begin{array}{c}\text { Functional } \\
\text { productivities }\end{array}$ & $\begin{array}{c}\text { Economic } \\
\text { productivities }\end{array}$ & $\begin{array}{c}\text { Department } \\
\text { investment } \\
\text { productivities }\end{array}$ \\
\hline $\begin{array}{l}\text { Productivity public investment } \\
\text { in Potosi }\left(\beta_{\text {potosi }}\right)\end{array}$ & & $\begin{array}{c}-0.1979 \\
(-0.70)\end{array}$ \\
\hline $\begin{array}{l}\text { Productivity public investment } \\
\text { in Santa Cruz }\left(\beta_{s c z}\right)\end{array}$ & & $\begin{array}{c}-0.2989 \\
(-0.34)\end{array}$ \\
\hline $\begin{array}{l}\text { Productivity public investment } \\
\text { in Tarija }\left(\beta_{\text {tarija }}\right)\end{array}$ & & $\begin{array}{l}0.3420 \\
(0.89)\end{array}$ \\
\hline $\begin{array}{l}\text { Productivity total national public } \\
\text { investment }\left(\beta_{\text {national }}\right)\end{array}$ & & $\begin{array}{l}2.9512 \\
(0.50)\end{array}$ \\
\hline \multicolumn{3}{|c|}{$\begin{array}{l}\text { Notes: } \\
\text { Real GDP per capita was regressed against functional, economic, and department expenditures, in } \\
\text { levels, to obtain estimates of productivities. } \\
\text { All variables, in levels, are expressed in U.S. dollars; the base year of all explanatory variables is } 2000 \text {. } \\
\text { Functional productivities were calculated for the period } 1940-2010 \text {. } \\
\text { Economic productivities were calculated for the period } 1965-2010 \text {. } \\
\text { Department productivities were calculated for the period } 1988-2010 \text {. } \\
\text { The ratio of total trade (exports + imports) on GDP is included in each specification as a control variable } \\
\text { t-statistics in parenthesis . } \\
\text { ** indicates significant at the } 5 \% \text { level of significance or above. }\end{array}$} \\
\hline
\end{tabular}

Government expenditure productivities were found by regressing expenditures - in levels, expressed in U.S. dollars, and with 2000 as the base year-according to functional, economic, and department classifications on real GDP per capita. The coefficients of the different types of government expenditures are estimates of these productivities. As can be observed in Table 1, significant and positive productivities are found for functional expenditures in infrastructure and economic expenditures in current expenditures by the central government. The productivities of capital expenditures by the central government and current expenditures by local government are found to be negative and significant, implying that these types of government expenditures have hindered, rather than enhanced, economic growth in the country. Department expenditure productivities are positive but insignificant for Cochabamba, Oruro, Tarija, and for aggregate national investment. The rest of the departments show negative but insignificant productivities.

With estimates of government expenditure productivities according to functional, economic, and department classifications, productivity to budget share ratios are estimated and regressed against real 
GDP per capita. ${ }^{19}$ Three sets of results are reported to differentiate between functional, economic, and department classifications. Since the dependent variable in all cases is the four-year forward moving average of real GDP per capita, serial correlation is expected in the error terms. Least-square estimators are unbiased but they could be overstating the relationship that exists between the dependent and the explanatory variables. To address this potential problem as well as other possible endogeneity issues, regressions are estimated using the generalized method of moments (GMM). ${ }^{20}$

\section{Functional classification results}

The GMM results for the period 1940-2010, illustrating the effect on economic growth of the productivity to budget share ratios by functional classification, are shown in Table 2.

There are several interesting findings that merit attention. First, the trade openness indicator (trade/gdp) is negative and significant in specifications 1-3. It is insignificant in specifications 4 and 5. This result reflects that for the 1940-2010 period, greater trade with other nations has not necessarily had a positive influence on the economic growth of Bolivia. The productivity to budget share ratio of total government expenditures $\left(\beta_{g e 1} / \phi_{g d p}\right)$, however, is for the most part positive and significant, denoting that for the period analyzed, government intervention has been conducive to higher growth. The disaggregated effect of government expenditures on economic growth, however, is more nuanced. The productivity to budget share ratio for defense is positively and significantly associated with GDP-per-capita growth: A unit increase in this ratio increases the per-capita real GDP growth rate by around 0.85 percentage points. Clearly, this result highlights the importance for growth of investment expenditures in this sector. However, it is a peculiar finding since Bolivia is not known for the might - in terms of number of personnel or capital equipment - of its armed forces. A plausible explanation is that expenditures in this sector have been efficient, and this efficiency is reflected in a host of

19. Productivity to budget share ratios are estimated by dividing the productivity estimates reported in Table 1 by the shares of each type of expenditure of total government expenditures. The periods used are 1940-2010 for functional expenditures, 1965-2010 for economic expenditures and 1988-2010 for department expenditures.

20. OLS estimators were found to be very similar to GMM estimators. However, since GMM results are more reliable, these are the only results presented and analyzed. See Wooldridge (2001) for a lucid treatment of what the GMM method can and cannot do. 


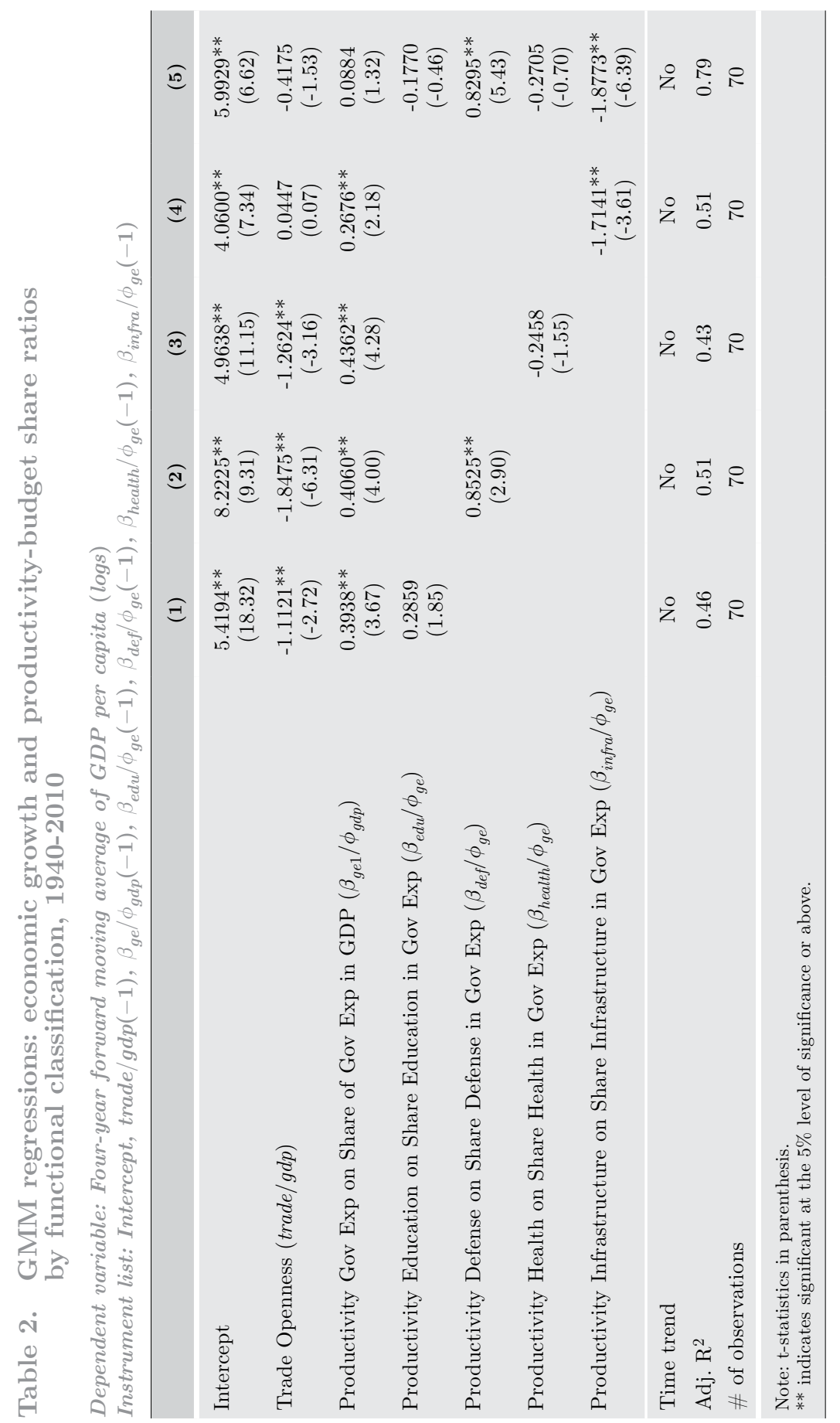


multiplier effects generated by this sector, with positive impacts on employment in complementary industries like construction and in service industries such as retail and banking. This result also runs counter to the bulk of research that finds a negative correlation between defense expenditures and growth (representative papers in this line are Obreja (2010), focusing on Romania, and Suleiman and Aamer (2003), who focus their analysis on Egypt, Israel, and Syria), but is consistent with the findings of several other authors (Bremmer and Kesselring (2007) analyzing Canada and Mexico, and Gerace (2002), focusing on the U.S.) who point to a positive correlation between defense expenditures and growth.

The productivity to budget share ratio for education is positive (although insignificant), consistent with most studies-notably Vera and Fiestas (2005), with an emphasis on Bolivia - that find a positive correlation between education and income growth.

The negative coefficients of the ratios $\beta_{\text {health }} / \phi_{\text {ge }}$ (statistically insignificant) and $\beta_{\text {infra }} / \phi_{\text {ge }}$ (statistically significant) point to the seemingly hindering effect these variables have had on growth since 1940. Despite the difficulty of drawing definitive conclusions from these results, they seem to indicate that with health and infrastructure what matters is not the quantity of resources devoted to these sectors, but rather the quality of health services that is ultimately provided as well as the real impact that infrastructure has on economic activity.

\section{Economic classification results}

Table 3 presents GMM results for the effect on economic growth of productivity to budget share ratios by economic classification. The period analyzed runs from 1965 through 2010.

Contrary to the functional classification findings, trade/gdp is for the most part positive and significant, implying that trade has had a positive influence on growth, at least between 1965 and 2010 . Consistent with the functional classification results, the productivity to budget share ratio of total government expenditures $\left(\beta_{g e 2} / \phi_{g d p}\right)$ is mostly positive and significant, demonstrating that total government expenditures have had a positive impact on income growth during the period analyzed. Once again, however, the disaggregated analysis of public expenditures points to a more complicated story. Productivity to budget share ratios for current and capital expenditures by the 


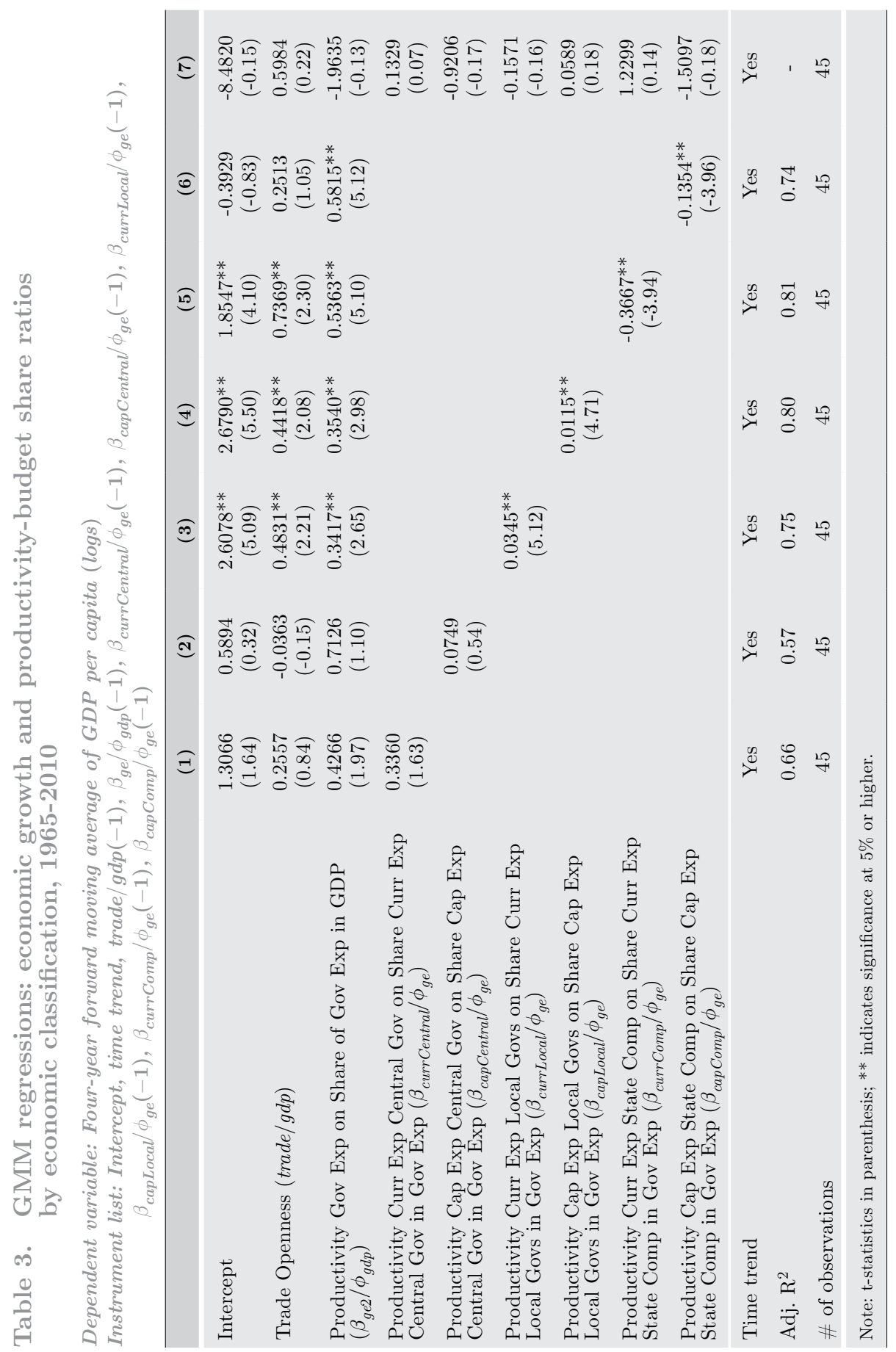


central government are insignificant, indicating the seeming irrelevance of centralized expenditures on growth. Current and capital expenditure ratios for local governments are significant and positive, highlighting the importance of decentralized public expenditures. Productivity to budget share ratios for current and capital expenditures by governmentrun companies are both negative and significant, demonstrating the hindering effect state companies have had on economic growth.

The picture that emerges from these results is that expenditures that are more decentralized, i.e., made by local and regional governments, tend to generate conditions for more growth. Conversely, centralized expenditures - whether current or capital - and those carried out by state companies, have had a minimal and even negative impact on growth since 1965 .

\section{Department classification results}

The GMM findings showing the effect on economic growth of productivity to budget share ratios by department classification appear in Table 4. The period of analysis runs from 1988 to $2010 .^{21}$

As is the case with the economic classification results, trade with other countries seems to have had a largely positive influence on economic growth. Unlike the results observed with functional and economic classifications, however, the productivity to budget share ratio of total government expenditures $\left(\beta_{g e 3} / \phi_{g d p}\right)$ is for the most part negative but insignificant, implying that total government expenditures have hindered economic growth in the country. At the disaggregated level, the results are once again more subtle. Of the nine departments in Bolivia, only Santa Cruz has made a positive and significant contribution to the country's growth. A unit increase of this department's productivity to budget share ratio $\left(\beta_{s c z} / \phi_{g e}\right)$ increases real GDP per capita by 2.56 points, demonstrating the considerable impact of this department on the economic well-being of the country. Other departments-Beni, Cochabamba, Chuquisaca, Oruro, and Tarija - also seem to have a positive effect on growth, but these effects are statistically insignificant. The productivity to budget share ratio for La Paz is negative and significant, implying that investment in this department has had a

21. It is important to point out that results presented in Table 4 account for a sample with only 22 observations. The limited availability of data disaggregated at the department level is a cause of concern, hence any conclusions that may arise from these results should be handled with caution. 


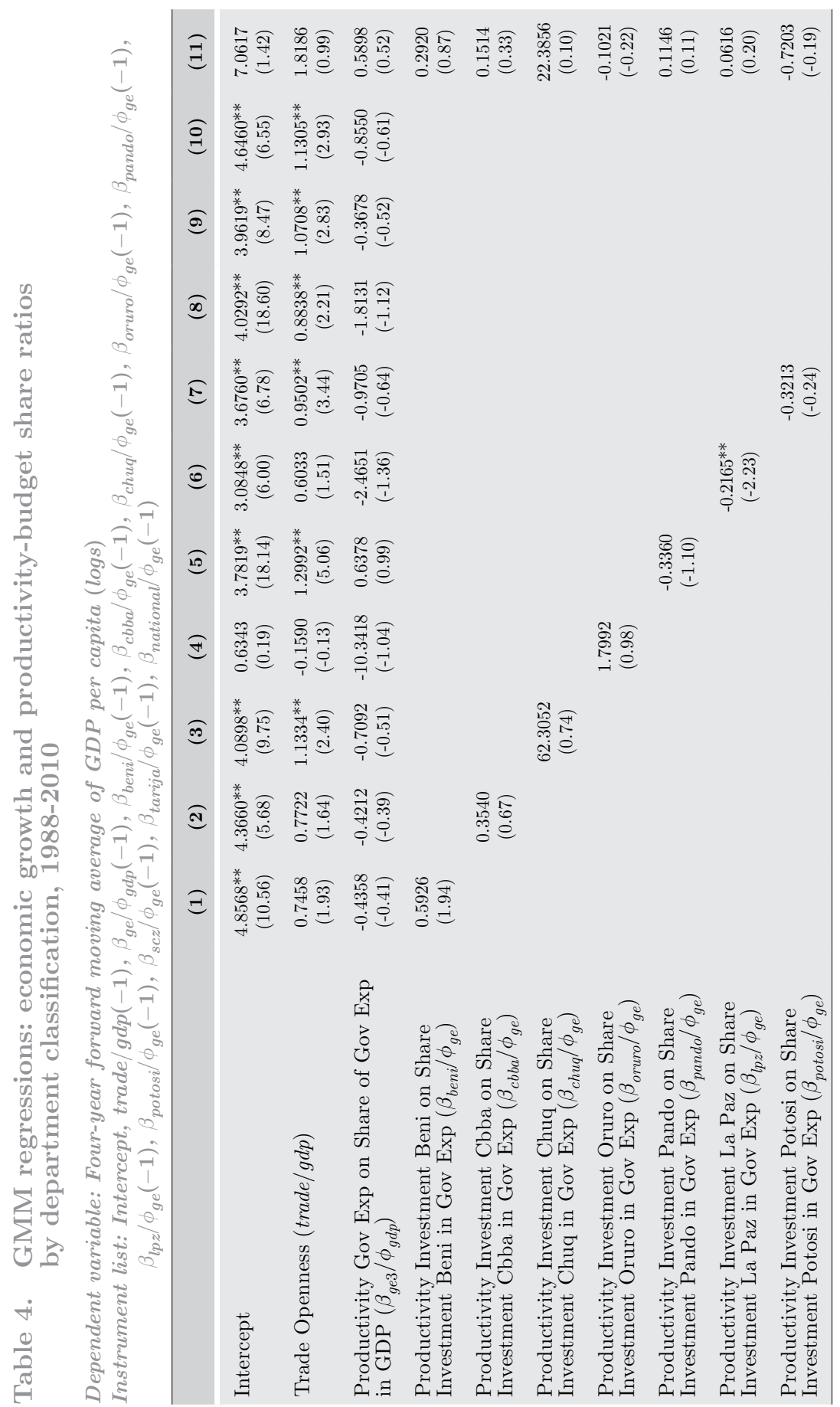




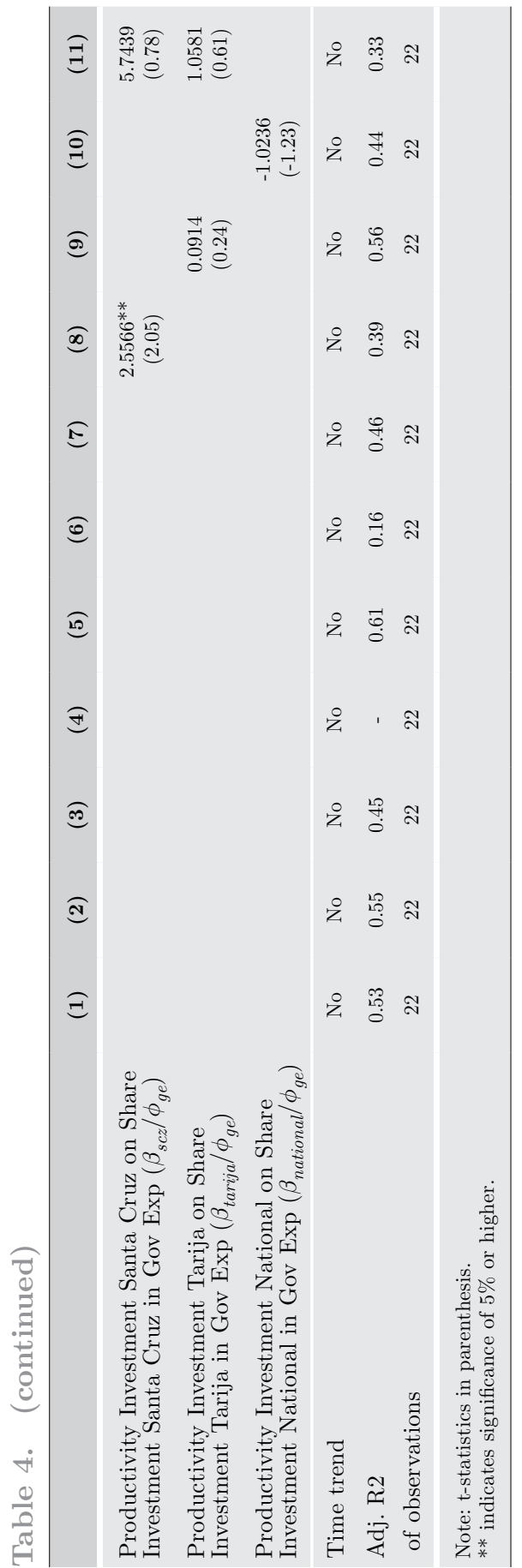


negative impact on Bolivia's growth. The productivity to budget share ratios for Pando and aggregate national investment are negative but insignificant, denoting little impact on growth.

\section{Conclusions}

This paper investigates the relationship between economic growth, as measured by real GDP per capita, and productivity to budget share ratios according to functional, economic, and department classifications. Having previously analyzed a theoretical model of government expenditures whereby productivity to budget share ratios are utilized to determine the most efficient allocation of government resources, the empirical findings suggest that functional expenditures in the defense sector represent the best way to induce growth in the country. Likewise, economic expenditures - current or capital expenditures - decentralized at the local or regional levels generate a positive impact on growth. Finally, in reference to department classification expenditures, the results indicate that investment in the Department of Santa Cruz is the most direct way to generate economic growth in the country. The findings also indicate the need to improve the productivity of all types of government expenditures, as it is this productivity that ultimately determines the direction in which different types of government expenditures affect economic growth.

Despite some important shortcomings - particularly in regard to the limited amount of information in some cases and to the embedded difficulty of discerning the quality of different types of expendituresthe results presented here offer an initial assessment of how different types of government expenditures have contributed to Bolivia's economic growth during the last several decades. 


\section{REFERENCES}

Abizadeh, S. and J. Gray (1985), "Wagner's law: A pooled time-series cross-section comparison," National Tax Journal, 88: 209-18.

Arrow, K. and M. Kurz (1970), Public Investment, the Rate of Return, and Optimal Fiscal Policy. Baltimore: The Johns Hopkins University Press.

Aschauer, D. (1998), "Optimal financing by money and taxes of productive and unproductive government spending: Effects on economic growth, inflation, and welfare," Levy Economics Institute Working Paper No. 241, retrieved from http://ssrn.com/abstract $=115025$.

Barro, R. (1990), "Government spending in a simple model of endogenous growth," Journal of Political Economy, 98(5): 103-25.

Barro, R. (1991), "Economic growth in a cross-section of countries," Quarterly Journal of Economics, 106: 407-44.

Bayraktar, N. and B. Moreno-Dodson (2010), "How can public spending help you grow? An empirical analysis for developing countries," World Bank Policy Research Working Paper No. WPS 5367.

Bremmer, D. and R. Kesselring (2007), "The impact of defense spending on GDP: The case of North America," Rose-Hulman Institute of Technology Working Paper.

Devarajan, S., V. Swaroop and H. Zou (1996), "The composition of public expenditure and economic growth," The Journal of Monetary Economics, 37: $313-44$.

Dickey, D. and W. Fuller (1979), "Distribution of the estimators for autoregressive time series with a unit root," Journal of the American Statistical Association, 74: $427-31$.

Dickey, D. and W. Fuller (1981), "Likelihood ratio statistics for autoregressive time series with a unit root," Econometrica, 49(4): 1057-72.

Fölster, S. and M. Henrekson (2001), "Growth effects of government expenditure and taxation in rich countries," European Economic Review, 45(8): 1501-20.

Gerace, M. (2002), "US military expenditures and economic growth: Some evidence from spectral methods," Defence and Peace Economics, 13(1): 1-11.

Hakro, A. (2009), "Size of government and growth rate of per capita income in selected Asian developing economies," International Research Journal of Finance and Economics, 28: 52-65.

Lindauer, D. and A. Velenchik (1992), "Government spending in developing countries: Trends, causes, and consequences," World Bank Research Observer, 7(1): 59-78.

Machicado, C., P. Estrada and X. Flores (2010), "Is fiscal policy enough for growth? A simulation analysis for Bolivia," Institute for Advanced Development Studies, Development Research Working Paper No. 04/2010. 
MacKinnon, J. (1991), "Critical values for cointegration tests in long-run economic relationships," in R. Engle and C. Granger, eds., Readings in Cointegration. New York: Oxford University Press.

Nurudeen, A. and U. Abdullahi (2010), "Government expenditure and economic growth in Nigeria, 1970-2008: A disaggregated analysis," Business and Economics Journal, 2010(4): 1-11.

Obreja, L. (2010), "The impact of defense expenditures on economic growth," Romanian Journal of Economic Forecasting, 4: 148-67.

Phillips, P. and P. Perron (1988), "Testing for a unit root in time series regression," Biometrika, 75: 335-46.

Romero-Avila, D. and R. Strauch (2008), "Public finances and long-term growth in Europe: Evidence from a panel data analysis," European Journal of Political Economy, 24(1): 172-91.

Sugata, G. and A. Gregoriou (2008), "The composition of government spending and growth: Is current or capital spending better?" Oxford Economic Papers, 60(3): 484-516.

Suleiman, A. and A. Aamer (2003), "Government expenditures, military spending and economic growth: Causality evidence from Egypt, Israel and Syria," Journal of Policy Modeling, 25(6-7): 567-83.

Vera, W. and I. Fiestas (2005), "Exploring the link between public spending and poverty reduction lessons from the 90s," World Bank Institute Working Paper, Stock No. 37252.

Wagner, A. (1883), Grundlegung der PolitischenÖkonomie, $3^{\text {rd }}$ edition, Leipzig: C. F. Winter.

Wooldridge, J. (2001), "Applications of generalized method of moments estimation," Journal of Economic Perspectives, 15(4): 87-100. 


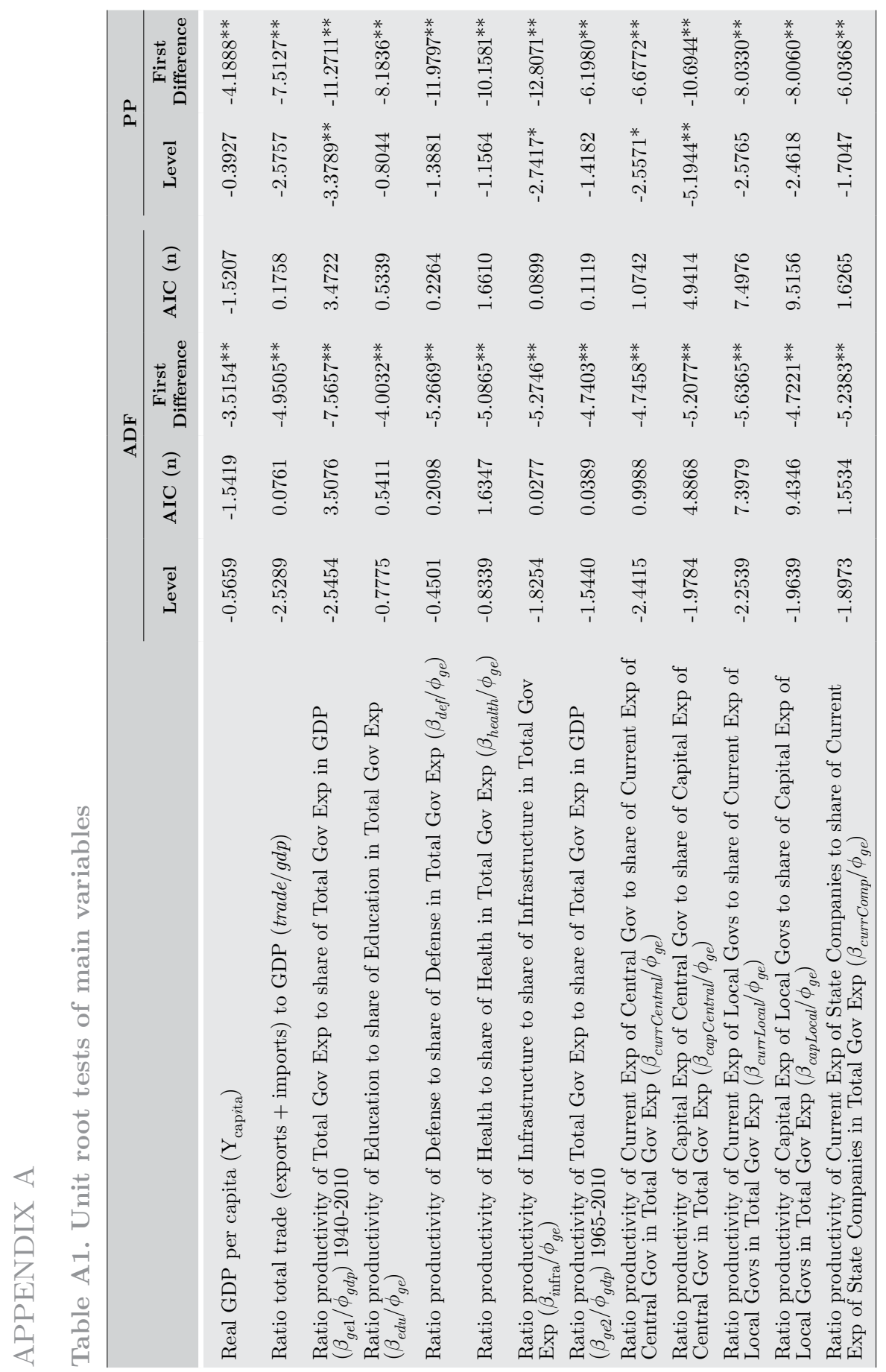




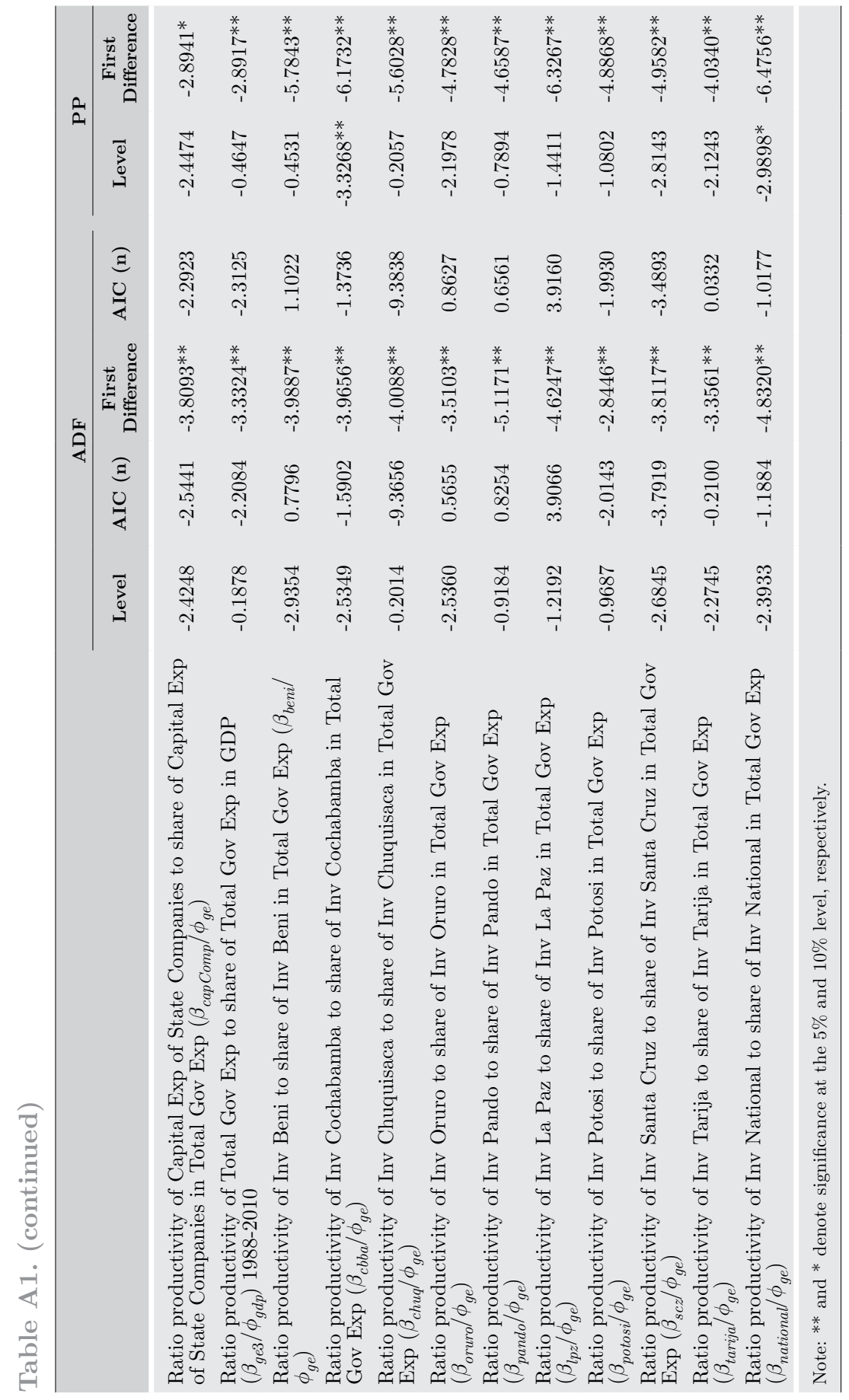


